\title{
Integrating ICT into Teaching and Learning Biology: A Case for Rachuonyo South Sub-County, Kenya
}

\author{
Gideon Mwanda ${ }^{1}$, Samwel Mwanda $^{2}$, Ronnie Midigo ${ }^{3}$, John Maundu ${ }^{1}$ \\ ${ }^{1}$ Department of Education Computer Technology, Kenyatta University, Nairobi, Kenya \\ ${ }^{2}$ Department of Education Communication and Technology, University of Nairobi, Nairobi, Kenya \\ ${ }^{3}$ Institute of Anthropology, Gender and African Studies, University of Nairobi, Nairobi, Kenya
}

\section{Email address:}

gmmwanda@gmail.com (G. Mwanda),somwanda@uonobi.ac.ke (S. Mwanda),ronniemidigo@gmail.com (R. Midigo), maundu.john@ku.ac.ke (J. Maundu)

\section{To cite this article:}

Gideon Mwanda, Samwel Mwanda, Ronnie Midigo, John Maundu. Integrating ICT into Teaching and Learning Biology: A Case for Rachuonyo South Sub-County, Kenya. International Journal of Education, Culture and Society. Vol. 2, No. 6, 2017, pp. $165-171$. doi: $10.11648 /$ j.ijecs. 20170206.12

Received: March 3, 2017; Accepted: March 28, 2017; Published: November 28, 2017

\begin{abstract}
The purpose of this study was to find out the extent of integration of computer technology into teaching and learning Biology in secondary schools of Rachuonyo South Sub-County, Kenya. The target population consisted of students and biology teachers in the Sub-County. Data was collected by use of questionnaires and an observation check list. From the study, most schools had few computers; teachers had inadequate training on use of computer applications; most teachers did not use computer technology for personal growth and instructional purposes. Inadequate number of computers in the sampled schools was the major challenge facing the integration of computer technology into the instruction process. The study recommends increased accessibility of computers, adequate training on use of computer technology and development of a policy framework to guide on the path to effective computer integration into instruction process.
\end{abstract}

Keywords: Computer, Technology, Biology, Constructivist Learning, Attitude, Education

\section{Introduction}

Use of information and technology in education is one way through which learner achievement can be enhanced [1]. In line with changes in the society, the $21^{\text {st }}$ century economy requires school graduates to be well conversant with modern electronic knowledge, embracing computer technology and other forms of media so as to remain competitive in the global employment market. This indicates that learners without literacy in computer technology are at risk of being left out of global employment opportunity. Learning institutions therefore have opportunity to improve performance skills and enter into the service sector economy by adopting use of computer technology. This will ensure that learners have the skills required for the ever increasingly competitive labour market.

In Kenya, introduction of free secondary education witnessed increasing number of students' enrolment yet the number of teachers remained almost constant due to teacher employment freeze by the government of Kenya [2]. This notwithstanding, teachers have the duty of insuring that their instructional duties are performed to the best standards available. Kenyan education system is marked with a lot of wastage and poor performance in national examinations [3]. This however needs to be stemmed and improved. The poor performance can be attributed to poor or inappropriate instructional methods due to lack of instructional materials in schools, overcrowded curriculum denying students adequate time to grasp basic principles and concepts learned and as well as over enrolment leading to overcrowded classrooms where teachers cannot provide students with individualized attention. Consequently, there is need for a change in methods of instruction to include use of strategies which can increase learner participation in the learning process. Such may include use of computer technology in management and delivery of instructional duties.

Studies indicate that use of computer technology improves quality of instruction by increasing learner participation and by assisting teachers in the complex task of managing and 
supporting instructional programs in schools [4] [5]. For instance, with computer technology, teachers can bring events of far distance in time and space into the classroom for lesson discussion. Similarly, teachers can keep and retrieve information records, communicate with parents and even carry out assessment of learning with ease and speed using computer technology. Reference [6] suggests that when teachers effectively integrate computer into classroom teaching and learning, the speed of the management of students' data, search for information and presentation of learning materials is greatly increases.

The introduction of computer for teaching and learning in Kenya is currently an ongoing process and is supported by key policy documents such as Sessional Paper number 1 of 2005 on a Policy Framework for Education, Training and Research; Kenya Vision 2030 and Kenya Education Commission Report on Totally Integrated Quality Education and Training (TIQET) [7] [8] [9]. Biology, one of the instructional subjects in Kenya, requires that learners develop high cognitive skills. This therefore requires adequate learning time. As a result, the syllabus is greatly compressed to be learnt over a short period of time. Consequently Biology has been poorly performed in National Examinations [10]. Similar trends are indicated in Homabay County where computation of the overall examination results by the mean grade of D+ (3 out of 12) for the year 2014. The Homa-Bay County result also indicate that just like in the national KCSE performance in Biology, most schools in the County also achieve low mean grades in Biology in the examinations.

\subsection{Problem Statement}

The Ministry of Education in Kenya, through a programme aimed at strengthening mathematics and sciences in secondary schools in Kenya (SMASSE) embarked on a countrywide training program of secondary school mathematics and science teachers on how to use computer technology for instruction. The aim of the SMASSE program is to integrate computer technology in teaching and learning sciences for better learner achievement. In Rachuonyo South Sub-County, in addition to the SMASSE training, MOE selected and provided five secondary schools with funds through Economic Stimulus Package to build ICT infrastructure and to improve capacity-building of teachers in the selected schools on integration of computer technology in teaching and learning [11]. Other schools have also acquired computers through the centre of excellence funds given to the schools by the MOE, Constituency Development Fund grants (C. D. F) or donations from well-wishers. Despite all theses, the use of computer technology for instruction in secondary schools of Rachuonyo South Sub-County, Kenya is still minimal. That notwithstanding, learner achievement in Biology and other science based disciplines continue to be poor. This therefore necessitated an investigation into the extent of integration of computer technology in instruction process and to recommend appropriate measures to facilitate effective integration of the technology into instruction process.

\subsection{Purpose and Objectives}

The purpose of this study was to find out the extent to which Biology teachers integrate computer technology into teaching and learning process. To achieve this, the study considered the extent to which secondary schools were equipped with computers, nature of teachers' knowledge and skills in computer technology, extent of use of computer applications for teaching of Biology, challenges faced in integrating computer technology into the teaching and learning process and attitude of teachers towards integration of computer technology into the teaching and learning process. The study was carried out in Rachuonyo South SubCounty, Homa-Bay County, Kenya. The findings of this study can form basis for acquisition of ICT resource necessary for improved learning and teaching of. Teachers Service Commission (TSC) can use the findings on teachers' levels of training and ability to use computer applications to recommended appropriate in-service trainings. Second, Kenya Institute of Curriculum Development (KICD) can focus attention on the challenges uncovered to revise the curriculum and include more information on how teachers can integrate computer into teaching and learning of Biology. The findings of this study may also inform policy guidelines for integration of ICT in education.

\subsection{Theoretical Context}

The study was based on social constructivist learning theory espoused by Vygotsky [12]. Social constructivist learning theory states that knowledge is constructed by individuals as they interact with other people and with the environment. Learning by interaction provides individuals with opportunity to share, reflect on prior knowledge experiences and also to compare the past and present experiences [13]. In order for students to effectively construct knowledge therefore, teachers must create collaborative learning environment where there are both means and opportunity to construct new understandings by assembling experiences from different sources. With this, learners explore their knowledge and continuously refine it by putting their ideas to work in the context of solving realistic problems. One way of providing a collaborative learning environment is to promote computer integration into the teaching and learning process [13]. This provides teachers and learners with opportunity to interact with each other, friends and the learning environment. When teachers and learners actively search for information stored in computer databases, they not only acquire variety but also create own interpretation and meaning of information retrieved. Biology as a subject has many concepts, terminologies procedures and methods that teachers and learners can learn best through inquiry based activities [14].

According to reference [14], constructivist learning advocates knowledge creation by the learner, emphasizes on student inquiry, problem solving, reflection and critical thinking. Indeed, use of computer technology applications supports constructivist learning approach. Computer word 
processor for example enables teachers and students to write and edit texts. Editing provides room for reflection on work done. Writing and editing make learning whole, authentic and real as espoused in the constructivist learning theory. Teachers and students who are far distance apart can communicate by using internet to share and discuss ideas. Similarly, information stored in computer data bases can be retrieved and shared by teachers and students, thus extending collaboration and sharing of ideas beyond confines' of classroom. In this study, it is envisaged that having good knowledge and skills on use of different computer applications motivate teachers to integrate computer technology into the teaching and learning process thereby promoting constructivist learning theory.

\section{Conceptual Framework}

The study has been conceptualized with integration of computer technology into instruction process as the dependent variable. Teacher's knowledge, attitude and skills in ICT and knowledge in planning and teaching Biology lessons influence integration of ICT in instructional processes. School environmental factors including availability of ICT infrastructure influence the frequency of use computer technology as proximal factors. This is as presented in figure 1 below.

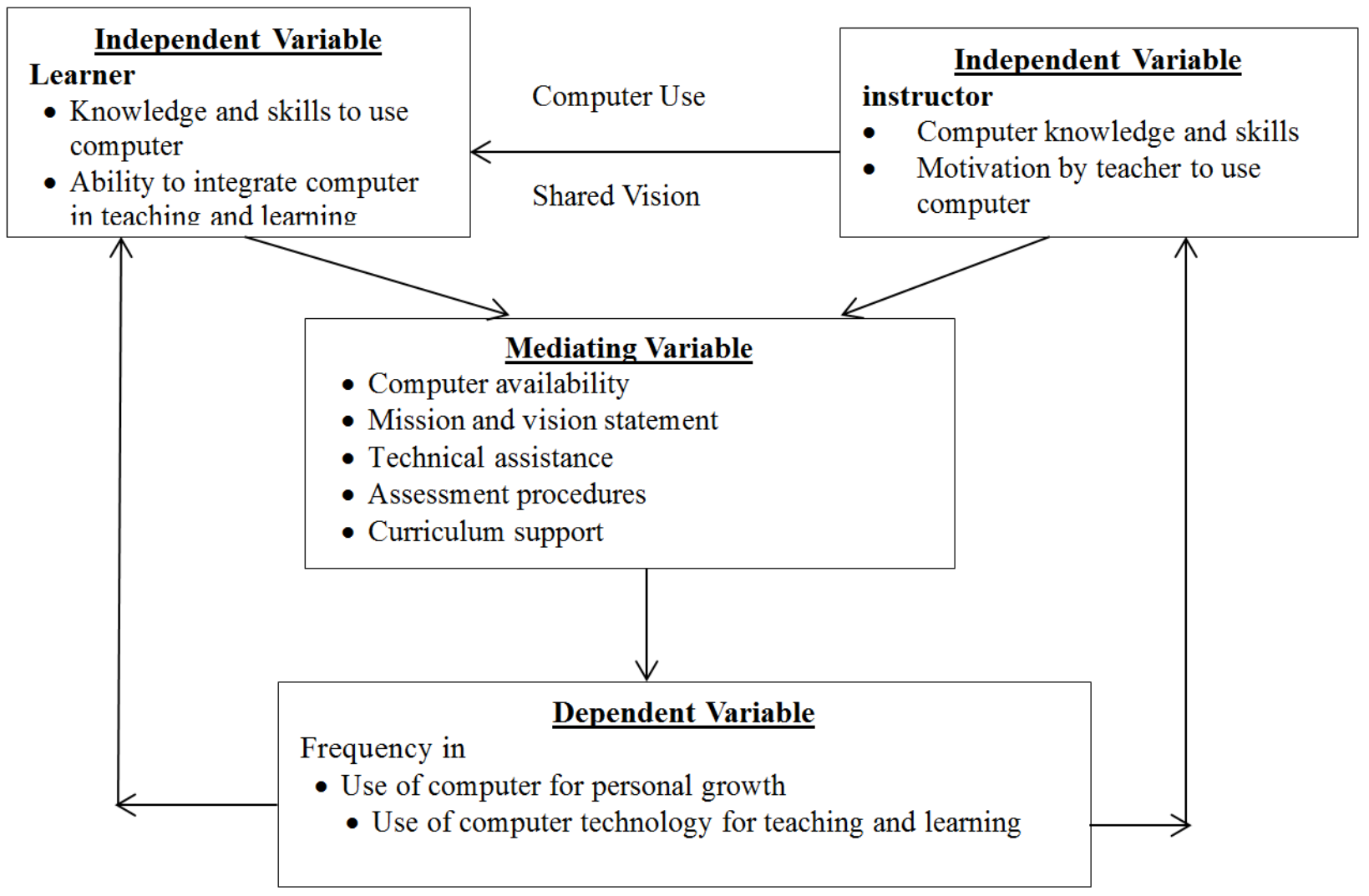

Figure 1. Conceptual Framework for Computer Integration into Instruction process.

\section{Methodology}

The study adopted descriptive survey design involving collection of data from a population sample by use of a questionnaire and an observation check-list. Target population comprised all Secondary schools in Rachuonyo South Sub-County. Sampling was done purposively to include all the schools with electricity supply necessary for ICT integration. This gave a total of 15 schools (out of 80 schools) with 56 subject teachers.

\section{Results}

Of the 56 teachers sampled, a total of 51 complete responses were obtained. This gave a response rate of $91.1 \%$. The results are presented according to the objectives of the study

\subsection{Demographic Characteristics of the Respondents}

Out of the total 51 participants, $39(76 \%)$ were males, while $12(14 \%)$, were females. Most of the teachers (61\%) were in the age bracket of 21-30 years, while $39 \%$ were in the age bracket 31 years and above. This shows that most of Biology teachers in Rachuonyo South Sub-County are below 31 years of age. Demographic data also revealed that, (90\%) of the teachers had (B. Ed) qualifications, (8\%) had Diploma in Education and (2\%) of the participants had Master's Degree qualifications. Those who specialized in Biology were $(63 \%)$ while $37 \%$ had Biology as their minor subject. Table 1 below shows the demographic characteristics of the respondents. 
Table 1. Demographic Characteristics of the Respondents.

\begin{tabular}{llll}
\hline $\mathbf{N}=\mathbf{5 1}$ & & Frequency & Percentages \\
\hline Gender & Male & 39 & 76 \\
& Female & 12 & 24 \\
Ages & $21-30$ & 31 & 61 \\
& $31-40$ & 16 & 31 \\
\multirow{5}{*}{ Academic qualifications } & $40-50$ & 4 & 8 \\
& Diploma & 4 & 8 \\
& B. Ed. Degree & 46 & 90 \\
Specialization in Biology & Masters & 1 & 2 \\
& Major & 32 & 63 \\
& Minor & 19 & 37 \\
\hline
\end{tabular}

\subsection{Extent to Which Schools Are Equipped with Computers}

The study established a wide variation in equipment of school with computers. While some schools had as many as 47 computers, other had only 2 computers. Most of the computers were also located in the administrative offices or computer laboratory. Table 2 below represents the number and location of computers in the sampled schools.

Table 2. Number and Location of Computers in Schools of the Study.

\begin{tabular}{|c|c|c|c|c|c|c|}
\hline School code & Principal's office & D/Principal's Office & Staffroom & Computer Laboratory & Examinations' Office & Total \\
\hline 1 & 1 & 0 & 0 & 5 & 1 & 7 \\
\hline 2 & 1 & 0 & 0 & 24 & 3 & 28 \\
\hline 3 & 1 & 1 & 0 & 16 & 1 & 19 \\
\hline 4 & 2 & 0 & 0 & 0 & 0 & 2 \\
\hline 5 & 2 & 0 & 0 & 0 & 1 & 3 \\
\hline 6 & 2 & 0 & 0 & 0 & 0 & 2 \\
\hline 7 & 1 & 1 & 0 & 0 & 2 & 4 \\
\hline 8 & 1 & 1 & 0 & 11 & 1 & 14 \\
\hline 9 & 1 & 1 & 0 & 0 & 3 & 5 \\
\hline 10 & 2 & 1 & 2 & 37 & 5 & 47 \\
\hline 11 & 1 & 1 & 0 & 20 & 1 & 23 \\
\hline 12 & 0 & 0 & 0 & 15 & 1 & 16 \\
\hline 13 & 1 & 0 & 0 & 8 & 1 & 10 \\
\hline 14 & 1 & 1 & 0 & 11 & 1 & 14 \\
\hline 15 & 1 & 0 & 0 & 0 & 2 & 3 \\
\hline Total 15 & 18 & 7 & 2 & 147 & 23 & 197 \\
\hline
\end{tabular}

The study identified that the low access to computers by the teachers could contribute to poor integration of computer technology in teaching and learning Biology in secondary schools in Rachuonyo South Sub-County. Inadequate numbers of computers as well as the location of the computers in laboratories is one of the major challenges of integrating computer technology in education. Studies indicate that location of computers in a school indicates how the computers are used [15] [16]. Computers located in a computer laboratory are mainly used to teach computer studies, location in examination office implies the computers are used mainly for preparation of examinations while location in Principal's or Deputy Principal's office implies the computers are used for administrative purposes [17]. According to reference [18], integration of computer into teaching and learning require that schools have computers located in laboratories, classrooms, and administrative offices to provide teachers with opportunity to explore new ways in which computer technology can change their personal productivity and professional practice. The implication here is, the rooms in which computers are located in a school may prevent teachers from accessing computers for teaching and learning duties.

\subsection{Nature of Computer Knowledge and Skills}

The study established that most of the teachers had received training in ICT. All the teachers had basic computer skill. Over $50 \%$ were capable of efficiently using computer technology applications. However, there was a variation of ability amongst the participants in using different computer applications. Most participants, (76.5\%) could efficiently utilize Word processor application, while only $70.6 \%$ and $51 \%$ of the participants could use Internet and Multimedia applications respectively. Other applications commonly used are the spread sheets, data bases, graphic tools and presentation. Most teachers who reported ICT training had higher usage of computer applications. This was as shown in table 3 below.

Table 3. Computer Knowledge and Skills.

\begin{tabular}{lllll}
\hline $\begin{array}{l}\text { Computer } \\
\text { Application (N=51) }\end{array}$ & \multicolumn{2}{l}{ Trained } & \multicolumn{3}{l}{ Not trained } \\
\cline { 2 - 5 } Frequency & Percentage & Frequency & Percentage \\
\hline Basic Computer skills & 51 & 100.0 & 0 & 0 \\
Word processors & 45 & 88.2 & 6 & 11.8 \\
Graphic tools & 34 & 66.7 & 17 & 33.3 \\
Spread Sheets & 43 & 84.3 & 8 & 15.7 \\
Data Bases & 38 & 74.5 & 13 & 25.5 \\
Presentation & 37 & 72.5 & 14 & 27.5 \\
Multimedia & 33 & 64.7 & 18 & 35.3 \\
Internet & 43 & 84.3 & 8 & 15.7 \\
\hline
\end{tabular}

The findings of the study indicate that teachers had basic computer skills as well as the basic applications necessary for 
integration of ICT in teaching and learning. This finding could be explained by the fact most of the teachers serving in the region had received training on ICT and had computers in their schools [11]. Further, a study conducted by reference [19] indicate that most higher learning institutions equip teachers with ICT skills to enable integration for effecting learning outcome in their professions as teachers.

\subsection{Use ICT in Instructional Process}

In order to ascertain nature of use of ICT, respondents were asked to indicate computer applications they used by responding to a set of Likert questions indicating extent of usage as daily (D), Weekly (W), all of the time (AOT) and Not applied (NA). The respondents were also asked to indicate how they used ICT in instructional processes. Section 4.4.1 and 4.4.2 below represents the findings

\subsubsection{Applications Used by Teachers}

Applications investigated included basic computer applications. The responses were as shown below

Table 4. Computer Applications Used.

\begin{tabular}{lllll}
\hline Computer application $(\mathbf{N}=\mathbf{5 1})$ & D (\%) & W (\%) & AOT (\%) & N/A (\%) \\
\hline Word processors & 33.3 & 37.3 & 21.6 & 7.8 \\
Graphic tools & 5.9 & 29.3 & 37.3 & 27.5 \\
Spread Sheets & 9.8 & 25.5 & 52.9 & 11.8 \\
Data Bases & 3.9 & 33.3 & 39.2 & 23.6 \\
Presentation & 5.9 & 21.6 & 29.4 & 43.1 \\
Multi media & 7.8 & 23.5 & 21.6 & 47.1 \\
Internet & 43.2 & 31.4 & 17.6 & 7.8 \\
Integrating computer into & 11.8 & 23.5 & 25.5 & 39.2 \\
instruction & & & & \\
\hline
\end{tabular}

Findings of the study revealed low usage of computer technology by the participants both for personal growth and in the instruction process. The most commonly used computer applications as identified by the participants were word and internet, $33.3 \%$ and $43.2 \%$ respectively, while presentations were least used (5.9\%). Participants who used computer to communicate with other teachers and friends were $52.9 \%$, for online learning $29.4 \%$ and for administration, $25.5 \%$. Power point presentation is a modern way of presenting lectures by teachers and presentation of discussion reports by students, but the application is used by only $5.9 \%$ of the participants on a daily basis. This finding indicates that teachers rarely use ICT applications including presentations in schools. It is possible that lack of knowledge and unavailability of other ICT infrastructure could contribute to this non usage of instructional ICT applications. A study conducted by reference [20] found out that teachers have little knowledge and skills of how to use presentation applications and that schools lack the PowerPoint projectors to project the power point slides.

\subsubsection{Use of ICT in Instructional Process}

Table 5 below represents how teachers used computers for instructional process.
Table 5. Frequency usage of Computer Applications in Teaching and Learning.

\begin{tabular}{lllll}
\hline Computer application (N=51) & D (\%) & W (\%) & AOT (\%) & N/A (\%) \\
\hline For administration & 25.5 & 11.8 & 37.3 & 25.5 \\
To prepare handouts & 19.6 & 27.5 & 37.3 & 15.7 \\
$\begin{array}{l}\text { For communication with other } \\
\text { teachers and friends }\end{array}$ & 52.9 & 23.5 & 13.7 & 7.8 \\
$\begin{array}{l}\text { To communicate to students } \\
\text { For online learning }\end{array}$ & 9.8 & 23.5 & 25.5 & 41.2 \\
$\begin{array}{l}\text { Power point presentation } \\
\text { during lectures }\end{array}$ & 29.4 & 13.7 & 15.7 & 41.2 \\
\hline
\end{tabular}

Teachers used ICT in instructional process for communicating with students, $41.2 \%$, online learning, $41.2 \%$ and administration, 25.5\%. Most teachers did not use PowerPoint presentations during lectures indicating that ICT is mostly used for communicating with students and for online learning. These findings might suggest that both teachers and students seem to have limited access to computers or that most teachers and students are not conversant with use of computer telecommunication tools. A study conducted by references [20] [21] indicated poor utilization of ICT in instructional processes for reasons of lack of adequate infrastructure and knowledge. When teachers use computer technology to prepare handouts, search for information in the web, communicate with other teachers, and administration purposes the technology adds value to the teachers' personal and professional growth, the teachers become more effective and efficient in service delivery to the students, parents to other school stakeholders [20].

\subsection{Attitude of Biology Teachers Towards Integration}

To ascertain attitude of teachers towards integration of ICT in teaching and learning Biology, likert type set of questions was asked requiring the respondents to indicate their levels of agreement with the statements. The findings were as presented in Table 6 below.

Table 6. Descriptive Statistics of Teachers' Attitude towards Computer Integration.

\begin{tabular}{llllll}
\hline Challenges (N=51) & $\begin{array}{l}\text { SA } \\
(\%)\end{array}$ & $\begin{array}{l}\mathbf{A} \\
(\%)\end{array}$ & $\begin{array}{l}\text { U } \\
(\%)\end{array}$ & $\begin{array}{l}\text { D } \\
(\%)\end{array}$ & $\begin{array}{l}\text { SD } \\
(\%)\end{array}$ \\
\hline $\begin{array}{l}\text { I will continue to use the idea of computer } \\
\text { for instruction in classroom }\end{array}$ & 78.4 & 19.6 & 2 & 0 & 0 \\
$\begin{array}{l}\text { Computer can be too addictive and waste } \\
\text { good learning time }\end{array}$ & 27.5 & 33.3 & 5.9 & 27.5 & 5.9 \\
$\begin{array}{l}\text { Using computer can positively contribute } \\
\text { to the learning }\end{array}$ & 68.6 & 29.4 & 1 & 0 & 2 \\
$\begin{array}{l}\text { Using computer in Biology class can make } \\
\text { students more interested in learning }\end{array}$ & 68.6 & 23.5 & 5.9 & 2 & 0 \\
\hline
\end{tabular}

Participants had positive attitude towards use of computer technology for instruction purposes with about $78.4 \%$ strongly agreeing that they would continue using the idea of computer for instruction in classroom. Teachers also agreed that computers positively contribute to learning and makes students more interested in learning. Improved computer technology support given to teachers would probably 
encourage teachers to use computer more often than what this study revealed. According to reference [20], teachers' attitude towards use of computer technology must be positive before the computer technology can be used for instruction. Teachers with positive attitude towards integrating ICT in teaching and learning must have had opportunity to expand their computer knowledge and skills through workshops, inservice or by providing a computer expert in schools to assist teachers when need arises [9].

\subsection{Challenges on Integration of Computer Technology}

Table 7 below represents the challenges affecting integration of ICT in teaching and learning biology as presented by the respondents.

Table 7. Challenges Met in Integration of Computerinto Teaching and Learning.

\begin{tabular}{lll}
\hline Challenge & Frequency & \% \\
\hline Lack of adequate computers in school & 38 & 74.5 \\
Lack of computer instructional software & 32 & 62.7 \\
$\begin{array}{l}\text { Students lack knowledge and skills to use computer } \\
\text { Teacher lack knowledge and skills to integrate computer }\end{array}$ & 32 & 62.7 \\
$\begin{array}{l}\text { Teacher not interested in computer technology for } \\
\text { instruction }\end{array}$ & 33 & 47.1 \\
$\begin{array}{l}\text { No of time to prepare computer lessons due to } \\
\text { commitments }\end{array}$ & 6 & 64.7 \\
$\begin{array}{l}\text { Head teachers are not interested in integration of } \\
\text { computer }\end{array}$ & 3 & 5.9 \\
$\begin{array}{l}\text { Integration of computer can interfere with syllabus } \\
\text { coverage }\end{array}$ & 13 & 25.5 \\
\hline
\end{tabular}

The study revealed that lack of enough computer hardware and software facilities in schools, $74.5 \%$ and $62.7 \%$ respectively, lack of interest in use of computer technology in teaching and learning process and lack knowledge and skills on computer technology applications by the students $(64.7 \%$ and $62.7 \%$ ) were the major challenges facing integration of computer technology in teaching Biology. Other studies have also revealed similar results [19] [20] [21]. Inadequate infrastructure and lack of training is therefore a major impediment to integration of ICT in instructional processes.

\section{Conclusions and Recommendations}

The study concludes that schools in Rachuonyo South Sub-County are not properly equipped with computers for proper integration ICT for teaching and learning Biology. While teachers in the study area seemed to have knowledge in computer applications, a majority mainly used it for communication and administration. Despite the positive attitude that teachers had towards integration of ICT in teaching and learning, most schools, most schools were not well equipped with ICT facilities to integrate use in instructional processes. Thus the study makes the following recommendations

a) More computers should be availed to secondary schools and located in staff rooms where the teachers can easily access them.

b) Secondary school teachers should be given adequate training on computer technology at the pre-service training institutions in order to acquire the knowledge and skills needed for integration of computer technology into the teaching and learning process.

c) The Government should formulate clear policies to guide the process of computer integration into the teaching and learning process in secondary schools.

\section{References}

[1] Beetham, H., \& Sharpe, R. (2013). Rethinking pedagogy for a digital age: Designing for 21 st century learning. routledge.

[2] Duflo, E., Dupas, P., \& Kremer, M. (2015). School governance, teacher incentives, and pupil-teacher ratios: Experimental evidence from Kenyan primary schools. Journal of Public Economics, 123, 92-110.

[3] Mwanda, G. M., Odundo, P., Midigo, R., \& Mwanda, O. S. (2016). Adoption of the Constructivist Learning Approach in Secondary Schools in Kenya: Focus on Learner Achievement in Biology by Class Category. US-China Education Review, 6 (1), 31-44.

[4] McKnight, K., O'Malley, K., Ruzic, R., Horsley, M. K., Franey, J. J., \& Bassett, K. (2016). Teaching in a digital age: How educators use technology to improve student learning. Journal of Research on Technology in Education, 48 (3), 194211.

[5] Dell, A. G., Newton, D. A., \& Petroff, J. G. (2016). Assistive technology in the classroom: Enhancing the school experiences of students with disabilities. Pearson.

[6] Newby, J. T., Stepich, D. A., Lehman, J. D., Russel, J. D., Ottenbreit-Leftwich, A. (2011). Educational Technology for Teaching and Learning ( $\left.4^{\text {th }} \mathrm{ed}\right)$. Boston; Pearson Education, Inc.

[7] Republic of Kenya, (2005a). Kenya Education Sector Support Program 2005-2010. Delivering quality education to all Kenyans. Nairobi: Government Printer.

[8] Kenya, Republic of (2007). Kenya Vision 2030. Nairobi: Ministry of Planning, National Development and Vision 2030.

[9] Koech, D. K. (1999). Totally Integrated Quality Education and Training, TIQET: Report of the Commission of Inquiry Into the Education System of Kenya. Republic of Kenya.

[10] KNEC, (2013). A report on Release of 2012 KCSE Examination Results. Nairobi: Kenya.

[11] Government of Kenya, Ministry of Education science and Technology, (2011). MOE/ICT 4E/A/1/4. Government secular. Retrieved 23 March 2017.

[12] Vygotsky, L., (1978). Mind in society. The development of higher psychological process. Cambridge MA: Harvard University Press.

[13] Kolb, D. A. (2014). Experiential learning: Experience as the source of learning and development. FT press.

[14] Ivers, K. S. (2003). A teacher's Guide to Using Technology in the Classroom, California: Libraries Unlimited. Kenya. 
[15] Tondeur, J., Krug, D., Bill, M., Smulders, M., \& Zhu, C. (2015). Integrating ICT in Kenyan secondary schools: An Exploratory case study of a professional development programme. Technology, Pedagogy and Education, 24 (5), $565-584$.

[16] Nikolopoulou, K., \& Gialamas, V. (2015). Barriers to the integration of computers in early childhood settings: Teachers' perceptions. Education and Information Technologies, 20 (2), 285-301.

[17] Nyaga, J. S. (2011). Comparison of Computer Assisted Instruction and Conventional Instructional Techniques in Science among Selected Secondary Schools in Embu District, Kenya. Un Published M. Ed Thesis, KU, Kenya.

[18] UNESCO. (2002). Information and communication technology in education: A curriculum for schools and programme of teacher development. Nitropdf/professional.
[19] Albion, P. R., Tondeur, J., Forkosh-Baruch, A., \& Peeraer, J. (2015). Teachers' professional development for ICT integration: towards a reciprocal relationship between research and practice. Education and Information Technologies, 20 (4), 655-673.

[20] Buabeng-Andoh, C. (2012). An exploration of teachers' skills, perceptions and practices of ICT in teaching and learning in the Ghanaian second-cycle schools. Contemporary Educational Technology, 3 (1), 36-49.

[21] Buabeng-Andoh, C. (2012). Factors influencing teachers' adoption and integration of information and communication technology into teaching: A review of the literature. International Journal of Education and Development using Information and Communication Technology, 8 (1), 136. 